\title{
KNOWLEDGE, ATTITUDES AND PRACTICES OF MOZAMBICAN PUBLIC EMPLOYEES ON THE PREVENTION OF COVID-19
}

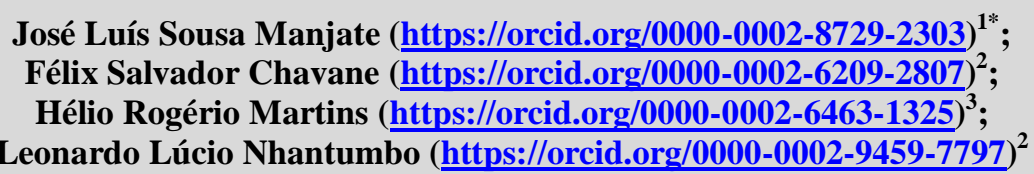

1 Department of School Nutrition and Health, Provincial Education Directorate - Maputo Province, Mozambique.

2 Higher School of Sport Sciences, Eduardo Mondlane University - Maputo, Mozambique.

3 Higher Institute of Health Sciences - Maputo, Mozambique.

*sousajos86@gmail.com

\section{Submitted: 15/05/2020. Accepted: 08/06/2020}

Published: 09/06/2020

\begin{abstract}
Objective: To analyze the level of knowledge, attitudes, and practices of Mozambican public employees on the prevention of COVID-19.

Methodology/Approach: 126 Mozambican public employees (79 men, 43 women and 4 who chose not to disclose their gender) answered a closed questionnaire applied through the Google Form online platform. The questionnaire was open for 5 days (two weekend and three business days).
\end{abstract}

Findings: The results suggest that employees are knowledgeable; however, efforts should be made to carry out educational actions to improve attitudes and change practices related to the prevention of COVID-19.

Research limitation/implications: Existence of some respondents who are not public employees due to online data collection, who were excluded from the study.

Originality/Value of the article: The conclusions of the study serve as a means of punctual intervention for Mozambican health entities as well as illustrating specific areas of concentration in education for the prevention of COVID-19. On the other hand, they enrich the specific scientific field, which is still empty of knowledge.

Keyword: sars-cov-2, coronavirus, social distancing, quarantine.

\section{CONHECIMENTOS, ATITUDES E PRÁTICAS DOS FUNCIONÁRIOS PÚBLICOS DE MOÇAMBIQUE EM RELAÇÃO À PREVENÇÃO DA COVID-19}

\section{RESUMO}

Objetivo: Analisar o grau de conhecimentos, atitudes e práticas dos funcionários públicos de Moçambique sobre a prevenção da COVID-19.

Metodologia/Abordagem: 126 funcionários públicos de Moçambique (79 homens, 43 mulheres e 4 que preferiram não revelar o sexo) responderam a um questionário fechado aplicado na plataforma online Google Form. O questionário esteve aberto durante 5 dias (dois de final de semana e três dias úteis).

Conclusões: Os resultados sugerem que os funcionários têm conhecimentos, contudo devem ser envidados esforços no sentido de serem realizadas acções educativas para o melhoramento das atitudes e mudança das práticas relativas à prevenção da COVID-19.

Limitação da pesquisa/implicações: Existência de alguns respondentes que não são funcionários públicos por conta da recolha de dados online, que acabaram sendo excluídos do estudo.

Originalidade/Valor do artigo: As conclusões do estudo servem como meio de intervenção pontual para as entidades de Saúde de Moçambique, como também ilustram áreas específicas de concentração na educação para prevenção da COVID-19. Por outro lado, enriquecem o campo científico específico, que ainda é vazio de conhecimentos.

Palavras-chave: sars-cov-2, coronavírus, distanciamento social, quarentena. 


\section{INTRODUCTION}

In the middle of December 2019, COVID-19 appeared in the Chinese City of Wuhan, located in Hubei Province. Studies aiming to unveil the etiology of the pathology are still ongoing, however it is known that its origin is from a family of coronavirus (Singhal, 2020). The first reports of the coronavirus outbreak refer to a wholesale market in Wuhan, where its users deal with different species of dead and live animals, including seafood (Rothan, 2020). According to Rothan (2020), from a chronological point of view, the first cases of COVID-19 infection were reported on December 18, 2019, where 5 patients were admitted with acute respiratory failure, in addition to the distress syndrome. Of these cases, a patient lost his life.

Subsequently, on 2 January 2020, 41 patients were hospitalized with the confirmation of COVID-19, after the declaration of the outbreak by the World Health Organization (WHO) China on 31 December 2019 (Rothan, 2020 ; World Health Organization, 2020e). Between 11 and 12 January, the World Health Organization received information from the Chinese health authorities that the outbreak was associated with exposure to food from the sea in the Chinese city of Wuhan. On the other hand, the details of the report included the report of 7 isolated cases for research (World Health Organization, 2020e). Following the preliminary results of the studies that were ongoing with the referred 7 cases, the genetic sequence of the new coronavirus, which would come to be called 2019-nCoV (Sohrabi, 2020), was confirmed.

On the other hand, while the concern with the etiology of the new coronavirus intensified, it spread very easily to neighboring countries and around the world, creating conditions for an international emergency (Sohrabi, 2020; World Health Organization, 2020d, 2020e). Therefore, on March 11, 2020, WHO declared COVID-19 as a global pandemic, thus guiding all nations of the world towards joint actions, with the aim of preventing and controlling the spread of the disease, in the meantime, studies continued in order to find suitable protocols for treatment and immunization (Hadis Fathizadeh, 2020).

Following the findings on the disease, on February 11, 2020, the WHO formally named the disease caused by 2019-nCoV by coronavirus Disease 2019, or simply COVID-19 (Sun, 2020). Along with this name, Sun (2020), highlights that on the same day the International Taxonomy Committee named 2019-nCov as coronavirus 2, with characteristics of Severe Acute Respiratory Syndrome, SARS-Cov-2 for short. Among the symptoms of COVID-19, fever, flu, pain or irritation in the throat, difficulty breathing, headache, increased body temperature beyond 37.5 degrees are highlighted and, in more severe cases, acute respiratory distress syndrome (ARDS), followed by anemia, acute cardiac injuries and adverse secondary infections (Sun, 2020; X, 2020; Zhang, 2020).

Little is known about the treatment of COVID-19, which is why studies continue to be developed by several Research Centers. However, according to the results of research conducted in Zhejiang, China, empirical therapy, based on the cure of symptoms and the isolation of patients with the pathology should be recommended, as it has so far shown significant positive effects (Zhang, 2020). However, given the lack of clarity about the forms of treatment and the absence of an immunization vaccine, prevention of contagion through different mechanisms has been recommended (World Health Organization, 2020c).

For this purpose, wash your hands with soap and water and / or sanitize them with alcoholgel, maintain social distance, use a nasal-oral mask, avoid touching your eyes, mouth and nose, if you have breathing difficulties, fevers and coughing up contacting medical teams, establishing isolation of cases of the disease and quarantine for suspected cases, as well as avoiding places of population confluence are some of the measures to prevent the spread of COVID-19 suggested by the World Health Organization and the Ministry of Health of Mozambique ( Ministry of Health of Mozambique, 2020c; World Health Organization, 2020c).

Despite the measures emanated by the world health entities, in general the cases of COVID19 tend to increase worldwide. Until the 18th of April, the prevalence was 2,160,207 infected people, with an incidence on the same day of 85,678 new cases and 146,086 deaths since the outbreak began (World Health Organization, 2020a, 2020b).

The World Health Organization (2020a, 2020b) reported for the same period under review that Mozambique had 28 cases of COVID-19. It should be noted that the first positive case for 
COVID-19 was detected on 22 March in the City of Maputo (Ministry of Health of Mozambique, 2020b).

Currently, the epicenter of the COVID-19 cases in Mozambique along with the City of Maputo, now includes the Province of Cabo Delgado. In general, in Mozambique, until the 18th of April, 8 cases of the infection were imported and 24 followed from local transmission, increasing the concern of government authorities (Ministry of Health of Mozambique, 2020a). In this perspective, the Mozambican Government and the Ministry of Health in particular have guided the population to follow the main preventive measures of COVID-19, with a greater focus on civic education actions on the etiology and the main preventive measures, through the media., lectures, web pages, social networks, free consultation contacts, among other means (Ministry of Health of Mozambique, 2020c).

On the other hand, through legal provisions, measures were taken to protect the Mozambican population, especially students of all levels of education, public and private employees and people with special needs (Boletim da República, 2020). Despite the preventive instructions from the Mozambican Government, the measures have not been fully observed in the population in general and among public employees in particular, especially with regard to the reduction of population clusters, the use of masks and the fulfillment of social distance. It should be noted that the public employee, in addition to the common guidelines through the means already mentioned, have been privileged with training, lectures and posters in the institutions where they work. It is based on the findings described above that there is an urgent need to analyze the knowledge, attitudes and practices of public officials in Mozambique on the prevention of COVID19.

The present study embarks on the expectation that the findings resulting from it may serve as a means of intervention by the health authorities of Mozambique, imbuing them with objective tools for intervention in the field of behavioral changes and practices of employees in particular and of the general population.

\section{MATERIAL AND METHODS}

The data collection for the present study was online, between the 11th and 16th of April, 2020, through a closed questions form, using the Google Form platform. This consisted of 22 questions, referring to sociodemographic information, knowledge, attitudes and practices on the prevention of COVID-19. However, based on the objectives of this research, answers to 16 questions were considered.

The questions that made up the questionnaire were designed based on a literature review, official information from the media and observation of the behavior of the population in general and public employees in particular, on the prevention of COVID-19.

The sample of the present survey consisted of 126 public employees from Mozambique, resulting from the exclusion of respondents who claimed not to be in the public service. Its distribution according to sex was 79 men, 43 women and 4 who preferred not to reveal it.

When the questionnaire was shared, representative distribution in the country was ensured, as well as coverage in different areas of interest to the civil service, through e-mail and various WhatsApp groups, whose members are located throughout the country.

All employees who participated in the survey were informed about the objectives of the survey, as well as about security in relation to confidentiality and guarantee of anonymity. On the other hand, it was previously clarified that by answering the questionnaire, they were freely giving consent the use of the information provided by them for the production of scientific articles.

This cross-sectional study followed a quantitative approach. The data were collected in a single moment, on the Google Form online platform, where the participants were free to answer closed questions, with a multiple choice option. It should be noted that the questionnaire was active for two weekend days and three working days. Access to the questionnaire was terminated when it was realized that the respondents no longer adhered. 
For data analysis, the answers obtained through the questionnaire were exported to an Excel sheet, subsequently made an exploratory analysis, basis on which respondents who were not in the public service were excluded.

Then, descriptive statistics were performed, namely the calculation of frequencies and averages for the numerical variables, at a $95 \%$ confidence interval and the calculation of percentages and proportions for the categorical variables, both related to the answers about knowledge, the attitudes and practices in the prevention of COVID-19 by public employees in Mozambique.

\section{RESULTS AND DISCUSSION}

One hundred and twenty-six (126) Professionals working in the public service answered the questionnaire. Of these, 63\% (79) were male, 34\% (43) female and 3\% (4) preferred not to reveal their gender, aged between 18 and 61 years (mean $=37.180 .75$ ).

The description of the basic knowledge about COVID-19 is shown in table 1. As can be seen, when asked about the source of information about the disease, $94.47 \%$ of employees answered that they received from social networks, radio and television, on the other hand $3.79 \%$ said they had access to knowledge through colleagues, friends and $1.74 \%$ said they did not follow the news about the disease.

Asked about the cause of COVID-19, 64.29\% said the pathology was caused by the coronavirus, $29.37 \%$ said the disease was caused by a virus strain called SARS-Cov-2 and $6.34 \%$ of the respondents declared he was not aware of the cause of COVID-19.

As for the symptoms of the disease, most of the public employees surveyed $(98.42 \%)$ said that fevers, headaches, flu, cough, sore throat, shortness of breath, pneumonia and kidney failure are the main symptoms of COVID-19.

Regarding the population at greatest risk of contracting COVID-19, most of the responses $(87.30 \%)$ converged for the elderly, chronically ill and health personnel, however $10.31 \%$ indicated that young people, children and athletes is that they had a higher risk, while $2.39 \%$ reported not having knowledge.

Table 1: Description of basic knowledge about COVID-19

\begin{tabular}{|c|c|c|}
\hline \multicolumn{3}{|c|}{ BASIC KNOWLEDGE ABOUT COVID-19 } \\
\hline Replies & No. Respondents & \% Respondents \\
\hline \multicolumn{3}{|c|}{ How have you received the news about COVID-19? } \\
\hline Social networks, Radio and Television & 119 & $94,47 \%$ \\
\hline Colleagues and Friends & 5 & $3,79 \%$ \\
\hline Do not follow the news & 2 & $1,74 \%$ \\
\hline \multicolumn{3}{|c|}{ What causes COVID-19? } \\
\hline Coronavirus & 81 & $64,29 \%$ \\
\hline SARS-Cov-2 & 37 & $29,37 \%$ \\
\hline Don't know & 8 & $6,34 \%$ \\
\hline \multicolumn{3}{|c|}{ What are the symptoms of COVID-19? } \\
\hline $\begin{array}{l}\text { Fevers, Headaches, Flu, Cough, Throat pain, } \\
\text { Shortness of breath, Pneumonia and Kidney failure }\end{array}$ & 124 & $98,42 \%$ \\
\hline Head trauma & 1 & $0,79 \%$ \\
\hline None & 1 & $0,79 \%$ \\
\hline \multicolumn{3}{|c|}{ Who is most at risk of contracting COVID-19? } \\
\hline Elderly, chronically ill and health personnel & 110 & $87,30 \%$ \\
\hline Children, Youth and Athletes & 13 & $10,31 \%$ \\
\hline Don't know & 3 & $2.39 \%$ \\
\hline
\end{tabular}

The responses inherent to the fundamental knowledge about COVID-19 confirm the expectation, because the radio, television and social media have permanently passed on timely and useful information about the disease.

Specifically, the television and public radio of Mozambique, in addition to the news services available on its grid and different advertising pieces, broadcast live the official update of the Government on the Pandemic of COVID-19, on the other hand, the Ministry of Health and the 
World Health Organization have a mechanism for updating information on the disease available on the Whatsapp platform and on the website (Ministry of Health of Mozambique, 2020c; World Health Organization, 2020f).

Along with these measures, training actions for public and private employees, lectures in hospitals and services provided by the private media are another mechanism for transmitting knowledge about COVID-19. The knowledge inherent to the prevention of COVID-19 is described in table 2 . Here it can be clearly seen that, when public employees were asked about the measures to be taken if they have symptoms of COVID-19, 30,16\% answered that they would contact a Health Unit, 65,87\% said they would contact COVID-19's Green Line, 3,17\% said they would selfmedicate with paracetamol and $0,80 \%$ said they did not know what measure they would take.

The answers on the question regarding the disease prevention mechanisms revealed that $84.92 \%$ of the sample recommends social distancing, hygiene with soap and water, disinfection with alcohol-gel, abstaining from being in crowded places, quarantine, isolation and use of the mask. However, $15,08 \%$ of respondents reported that sharing household items with a person coughing and coughing in the wrist or palm are appropriate ways of preventing the disease.

Still in the context of prevention, when asked about the foods that should be recommended, with a view to increasing immunity and, in this way, guaranteeing the body's defense against infectious agents, $94,44 \%$ of the employees pointed out foods with vitamin C and complex B as the most indicated, 2,39\% recommended foods with a lot of fat and drinks with high alcohol content and $3,17 \%$ said they did not know what foods should be consumed.

Although the information is available, it is possible to note that regarding preventive measures, there is still civic education work to be developed. It can be clearly seen that there is a considerable number of employees who are not clear about the measures to be taken if they are suspicious of COVID-19, on the other hand, a quarter of public employees who do not have control over, for example, coughing and sharing utensils with a respiratory patient. This scenario can be motivated by the excess of information coming from several sources and with different approaches, as well as the use made based on fake news created by strangers.

Table 2: Description of knowledge about the prevention of COVID-19

\begin{tabular}{|c|c|c|}
\hline \multicolumn{3}{|c|}{ KNOWLEDGE ON THE PREVENTION OF COVID-19 } \\
\hline Replies & No. Respondents & \% Respondents \\
\hline \multicolumn{3}{|c|}{ If you have any symptoms of COVID-19, what action should you take? } \\
\hline Contact a Hospital & 38 & $30,16 \%$ \\
\hline Contact the COVID-19 Green Line & 83 & $65,87 \%$ \\
\hline Taking paracetamol & 4 & $3,17 \%$ \\
\hline Don't know & 1 & $0,80 \%$ \\
\hline \multicolumn{3}{|l|}{ How is COVID-19 prevented? } \\
\hline $\begin{array}{l}\text { Distancing, Hygienization with soap and water, Disinfection with } \\
\text { alcohol, avoid agglomeration, quarantine, isolation and use of the } \\
\text { mask }\end{array}$ & 107 & $84,92 \%$ \\
\hline $\begin{array}{l}\text { Sharing household items with a person coughing and coughing } \\
\text { into the wrist or palm }\end{array}$ & 19 & $15,08 \%$ \\
\hline \multicolumn{3}{|c|}{ In the control of COVID-19, which foods should be consumed more to increase immunity? } \\
\hline Foods with Vitamin C and B & 119 & $94,44 \%$ \\
\hline High-fat foods and high-alcohol drinks & 3 & $2,39 \%$ \\
\hline Don't know & 4 & $3,17 \%$ \\
\hline
\end{tabular}

Awareness about the severity of the disease, the imminent risk of contagion for anyone and confidence in the National Health System are some of the key assumptions for defining attitudes by the population in general and public officials in particular. The information described in graphs 1 to 4 conveys the behavioral tendency of the respondents.

In this context, when confronted with whether COVID-19 was an important issue or problem in the community, 94,44\% assumed it as such. In another approach, answers about the possibility of becoming infected with the disease in the community revealed that $80,95 \%$ think it is 
possible, however $13,49 \%$ doubt that the infection may occur in their context and $3,17 \%$ say that there is no possibility contagion in its midst.

The positioning of public employees on a possible risk of contagion in the following 15 days, revealed that $42,15 \%$ considered it a high risk, 27,78\% considered an average risk, 1,59\% without risk and 9,52\% said they had no answer. Asked whether Mozambican public hospitals can effectively treat pathology, $43,86 \%$ of employees responded positively, $37,71 \%$ negatively and $16,67 \%$ said they had no response.
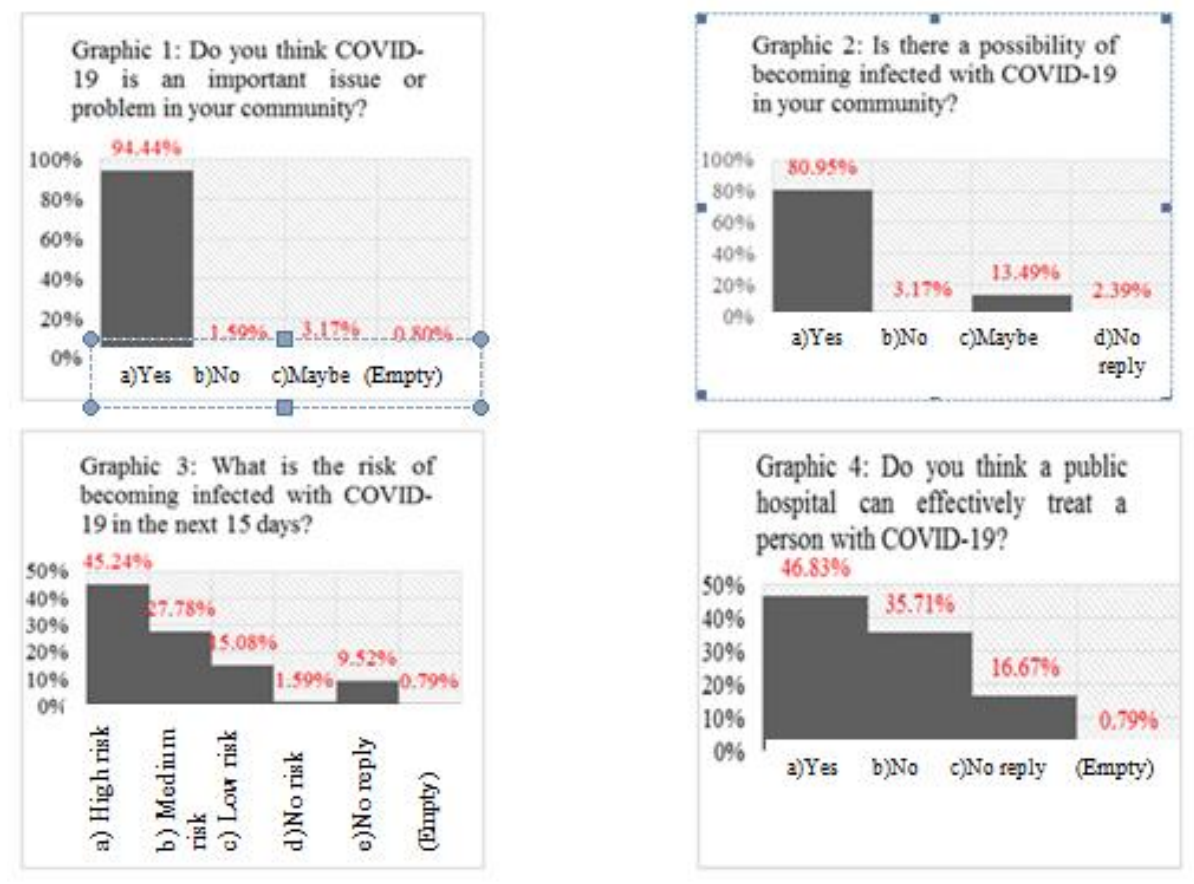

Regarding the responsibility for preventing contagion by COVID-19 in the community, $96,04 \%$ revealed that it was an individual obligation, of the government and other entities and $3,17 \%$ said it was the task of the head of the family and others. Table 3 illustrates the proportions of the responses.

Table 3: Description of responses inherent to the responsibility of preventing COVID-19 in the community

\begin{tabular}{l}
\hline \multicolumn{3}{c}{ ATTITUDES IN RELATION TO COVID-19 } \\
\hline \multicolumn{3}{c|}{ Replies } & No. Respondents & \% Respondents \\
\hline \multicolumn{2}{c}{ Who can prevent you, your family and community from becoming infected with } \\
COVID-19?
\end{tabular}

Although it is assumed that COVID-19 is an important problem in the community and that the responsibility for prevention is primarily individual, it is noteworthy that employees are incredulous about the possibility of possible contagion and the capacity for treatment in public hospitals.

This scenario points to a negligent conduct regarding the full compliance with the preventive measures, even though they have sufficient knowledge for action. 
In fact, it can be seen through the modus vivendi of the Mozambicans that the measures are carried out only in the eyes of the authorities, with evening meetings still prevailing in environments of population confluence, where alcoholic beverages are consumed, without the minimum observance of safety and individual protection measures. and collective against contamination by COVID-19 (Soico Televisão, 2020).

Table 4 illustrates the actions taken by public employees to prevent COVID-19 and how they would proceed in case of suspected infection. As can be seen, when asked about what they do for their own prevention and for the family, 53,37\% highlighted individual and concrete measures, such as hand washing, use of alcohol-gel, mask, gloves, not being in public places and isolation, on the other hand, 47,63\%, alongside these measures, highlights that she prays to God.

Regarding the challenges and difficulties faced in taking preventive measures, the lack of time $(6,45 \%)$, the lack of time and resources $(33,06 \%)$, the difficulty of access to hygiene products and protective equipment were highlighted. $(35,48 \%)$ and the need to convince others to allow preventive measures to be taken $(5,65 \%)$. In addition to the reported difficulties and challenges, $4,03 \%$ said they had no answer and $15,32 \%$ said they did not face any challenges or difficulties.

With regard to what they would do if they were suspicious of COVID-19 based on knowledge about symptoms, 4,05\% said they would be isolated at home doing nothing, without taking medication, but they also said they would go to church and speak to community leaders. . $43,89 \%$ stated that they would isolate themselves at home to take medication to lower their fever and relieve pain and drink lots of fluids. Still on the same question, 45,54\% revealed that they would be isolated, would go to a Health Unit and / or would contact a private doctor, on the other hand 5,69\% said that they would only be in isolation. It is noteworthy for this question that, although there were among the answer options the possibility of choosing to contact the green line for COVID-19, no respondent said that he would do so.

The practices of most employees expose a considerable gap and discrepancy between the knowledge they have and their attitudes and practices. As an illustration, it can be seen that almost all respondents answered correctly about the knowledge and the measures they practice in the context of individual and family prevention, however, paradoxically, half of these same employees were not able to point out appropriate measures in case of suspicion of COVID-19 and slightly less than half said they had some difficulty or challenge to comply with the preventive measures.

Table 4: Description of public employee practices in relation to COVID-19

\begin{tabular}{l|l|l}
\hline \multicolumn{1}{c}{ Replies } & No. Respondents & \multicolumn{1}{c}{ \% Respondents } \\
\hline \multicolumn{1}{c}{ What steps do you take to prevent you or your family from contracting COVID-19? } \\
\hline $\begin{array}{l}\text { I wash my hands, use alcohol, wear gloves, masks, avoid public } \\
\text { places and stay at home }\end{array}$ & 66 & $53,37 \%$ \\
\hline $\begin{array}{l}\text { I pray to God, wash my hands, use alcohol, wear gloves, masks, } \\
\text { avoid public places and stay at home }\end{array}$ & 60 & $47,63 \%$ \\
\hline \multicolumn{1}{c}{ What challenges or difficulties did you face when taking COVID-19 prevention measures? } \\
\hline Difficulty of time to take preventive measures & 8 & $6,45 \%$ \\
\hline Lack of time and resources to take preventive measures & 41 & $33,06 \%$ \\
\hline Difficulty in accessing hygiene products (alcohol, masks, etc.) & 44 & $35,48 \%$ \\
\hline $\begin{array}{l}\text { Needs to convince people around me, who didn't want me to be } \\
\text { aware }\end{array}$ & 7 & $5,65 \%$ \\
\hline I did not face any challenge or difficulties & 19 & $15,32 \%$ \\
\hline I do not have an answer & 5 & $4,04 \%$ \\
\hline \multicolumn{1}{c}{ What would you do now if you were suspicious of COVID-19? } \\
\hline $\begin{array}{l}\text { Staying at home / doing nothing, not taking medication, being } \\
\text { isolated, going to church and talking to a community leader }\end{array}$ & 5 & $4,05 \%$ \\
\hline $\begin{array}{l}\text { Stay at home and take medication to lower the temperature and } \\
\text { relieve pain, drink lots of fluids and be isolated. }\end{array}$ & 54 & $43,89 \%$ \\
\hline Stay isolated, go to the Health Unit, go to the private doctor & 56 & $45,54 \%$ \\
\hline Call green line for COVID-19 & 0 & $0 \%$ \\
\hline Stay isolated & 7 & $5,69 \%$ \\
\hline I do not have an answer & 1 & $0,83 \%$ \\
\hline
\end{tabular}


This scenario exposes the generalized devaluation lent to this pandemic, at least from a practical point of view. It is noted that there is an underlying "theoretical fear" in public employees in particular and in the population in general, but the actual prevention procedures are still a mirage, if evaluated according to the degree of contamination and lethality of this disease.

\section{CONCLUSION}

Most Mozambican public employees have access to information about COVID-19 and are able to approach it clearly.

A little more than half show a predisposition for behaviours conducive to personal prevention, actions capable of promoting family and community prevention and others show conduct that reveals that the problem belongs to others and the lack of trust in institutions and people.

Slightly less than half are not able to put into practice the knowledge they claim to have in relation to the prevention of contagion by the coronavirus, raising the idea of having to find new models of civic education on the subject, focusing on attitudes and practices.

\section{REFERENCES}

Decreto n. ${ }^{\circ}$ 12/2020 de 2 de Abril, 12/2020 C.F.R., República de Moçambique, (2020).

Hadis Fathizadeh, P. M., Mansooreh Momen-Heravi, Sounkalo Dao, S ،ükran Köse, Khudaverdi Ganbarov, Pasquale Pagliano, Silvano Espsoito, Hossein Samadi Kafil. (2020). <Protection and disinfection policies against SARS-CoV-2 (COVID-19).pdf>. Le Infezioni in Medicina, 2, 185-191.

Ministério da Saúde de Moçambique. (2020a, 14 de Abril de 2020). BOLETIM DIÁRIO COVID-19 N²8. Retrieved from http://www.misau.gov.mz/index.php/covid-19-boletins-diarios?limitstart=0.

Ministério da Saúde de Moçambique. (2020b, 22 de Março 2020). COVID-19: Boletins Diários. Retrieved from http://www.misau.gov.mz/index.php/covid-19-boletins-diarios?start=20.

Ministério da Saúde de Moçambique. (2020c, 15 de Abril). Sobre COVID-19. Retrieved from http://www.misau.gov.mz/index.php/informacao-sobre-coronavirus-covid-19.

Rothan, H. A. B., S. N. (2020). The epidemiology and pathogenesis of coronavirus disease (COVID-19) outbreak. J Autoimmun, 109, 102433. doi:10.1016/j.jaut.2020.102433.

Singhal, T. (2020). A Review of Coronavirus Disease-2019 (COVID-19). Indian J Pediatr, 87(4), $281-286$. doi:10.1007/s12098-020-03263-6.

Sohrabi, C. A., Z.; O'Neill, N.; Khan, M.; Kerwan, A.; Al-Jabir, A.; Losifidis, C.; Agha, R. (2020). World Health Organization declares global emergency: A review of the 2019 novel coronavirus (COVID-19). Int J Surg, 76, 71-76. doi:10.1016/j.ijsu.2020.02.034.

Soico Televisão (Writer). (2020). ESTADO DE EMERGÊNCIA: Muitos cidadãos desafiam as autoridades e continuam a vender e consumir álcool às escondidas. In STV (Producer). Jornal da Noite: STV.

Sun, P. L., X.; Xu, C.; Sun, W.; Pan, B. (2020). Understanding of COVID-19 based on current evidence. J Med Virol. doi:10.1002/jmv.25722.

World Health Organization. (2020a, 16 April 2020). Coronavirus disease 2019 (COVID-19) Situation Report -87. Retrieved from https:/www.who.int/docs/default-source/coronaviruse/situation-reports/20200416-sitrep-87-covid19.pdf?sfvrsn=9523115a_2.

World Health Organization. (2020b, 19 April 2020). Coronavirus disease 2019 (COVID-19)Situation Report -89. Retrieved from https://www.who.int/docs/default-source/coronaviruse/situation-reports/20200418-sitrep-89-covid19.pdf?sfvrsn=3643dd38_2.

World Health Organization. (2020c, 31 March 2020). Coronavirus disease (COVID-19) advice for the public. Retrieved from https://www.who.int/emergencies/diseases/novel-coronavirus-2019/advice-for-public.

World Health Organization. (2020d). <Novel Coronavirus (2019-nCoV) SITUATION REPORT-2 JANUARY 2020.pdf>. Retrieved from https://www.who.int/docs/default-source/coronaviruse/situation-reports/20200122-sitrep-22019-ncov.pdf?sfvrsn=4d5bcbca_2. 
World Health Organization. (2020e). <Novel Coronavirus(2019-nCoV)SITUATION REPORT-1.pdf>. Retrieved from https://www.who.int/emergencies/diseases/novel-coronavirus-2019/situation-reports/.

World Health Organization. (2020f, 15 April 2020). Rolling updates on coronavirus disease (COVID-19). Retrieved from https://www.who.int/emergencies/diseases/novel-coronavirus-2019/events-as-they-happen.

X, H. C. W. Y. L. (2020). Clinical features of patients infected with 2019 novel coronavirus in Wuhan, China. Lancet, 30183-30185. doi:10.1016/S0140-6736 (20).

Zhang, X. C., H.; Hu, J.; Lian, J.; Gu, J.; Zhang, S.' Ye, C.; Lu, Y.; Jin, C.; Yu, G.; Jia, H.; Zhang, Y.; Sheng, J.; Li, L.; Yang, Y. (2020). Epidemiological, clinical characteristics of cases of SARS-CoV-2 infection with abnormal imaging findings. Int J Infect Dis. doi:10.1016/j.ijid.2020.03.040.

\section{INTEREST CONFLICTS}

The authors report that there are no conflicts of interest in the study.

Before presented in https://preprints.scielo.org/index.php/scielo/preprint/view/114/136

\section{Collaborators}

Félix Salvador Chavane, Hélio Rogério Martins and Leonardo Lúcio Nhantumbo contributed to the review and correction of the article;

José Luís Sousa Manjate participated in all stages of article production. 